\title{
Uji Cold Shock Spermatozoa Babi Landrace terhadap Viabilitas dan pH Semen dengan Lama Waktu Berbeda
}

\author{
Hironimus Sanan ${ }^{\mathrm{a}}$, dan Agustinus A. Dethan ${ }^{\mathrm{b}}$ \\ ${ }^{a}$ Fakultas Pertanian, Universitas Timor, Kefamenanu, TTU - NTT, 85613, Indonesia. \\ ${ }^{b}$ Fakultas Pertanian, Universitas Timor, Kefamenanu, TTU - NTT, 85613, Indonesia.
}

\section{Article Info}

\section{Article history:}

Received 17 April 2016

Received in revised form 27 Mei 2016

Accepted 17 Juni 2016

\section{Keywords:}

Cold Shock

Spermatozoa

Babi Landrace

Viabilitas

Semen

\begin{abstract}
Abstrak
Kualitas semen segar yang digunakan dalam inseminasi buatan dipengaruhi proses pembekuan. Problema pembekuan semen segar yait adanya pengaruh cold shock. Penelitian ini bertujuan untuk mengetahui viabilitas dan derajat keasaman (pH) semen. Pada penelitian ini digunakan semen pejantan babi Landrace berusia 1 tahun 8 bulan. Semen dikoleksi dengan metode manual menggunakan induk buatan Penelitian ini menggunakan metode eksperiment menggunakan Rancangan Acak Lengkap (RAL) dengan empat perlakuan (0 menit, 30 menit, 60 menit, 90 menit) dan empat ulangan sehingga terdapat 16 unit percobaan. Penelitian ini diawali dengan melakukan penempungan semen segar babi Landrace bertempat di Tunbakun, selanjutnya semen segar langsung dievaluasi makroskopis dan mikroskopis di laboraturium Faperta Universitas Timor. Kemudian dilakukan perlakuan cold shock pada setiap ulangan, setelah itu diamati viabilitas dan derajat keasaman $(\mathrm{pH})$ semen. Hasil penelitian yang mempunyai persentase terbaik adalah R0 (0 menit) dimana viabilitas spermatozoa $85.00 \%$ dan $\mathrm{pH} 8.00$ dan $\mathrm{R} 1$ (30 menit) viabilitas spermatozoa 55.38 dan $\mathrm{pH} 8.00$. Sedangkan rataan viabilitas spermatozoa dan $\mathrm{pH}$ pada R2 dan R3 mengalami penurunan yaitu 33.63\%, 7.75 dan 26,75\%, 7.25. Hasil analisis statistik menunjukkan bahwa rataan persentase spermatozoa hidup karena cold shock dengan lama waktu berbeda adalah menunjukkan perlakuan berbeda sangat nyata $(\mathrm{P}<0.01)$. Sedangkan derajat keasaman tidak memberikan pengaruh yang nyata $(\mathrm{P}>0.05)$. $\odot 2016$ dipublikasikan oleh JAS.
\end{abstract}

\section{Pendahuluan}

Babi Landrace adalah salah satu jenis babi yang banyak dipelihara di Indonesia khususnya Provinsi Bali, dimana babi merupakan salah satu sumber gizi dan sumber daging yang bernilai ekonomi cukup tinggi. Dikatakan memiliki nilai ekonomi yang cukup tinggi karena memiliki kemampuan beranak yang baik yakni dua kali dalam setahun, pertumbuhan yang cepat, kemampuan mengembalikan modal cukup tinggi, efisien dalam menggunakan pakan $(75-80 \%)$, proporsi karkasnya tinggi (65-80\%), limbah yang dihasilkan dapat dijadikan sebagai pupuk, sumber energi biogas, dan pakan ikan (Ardana dan Harya Putra, 2008)

Kabupaten Timor Tengah Utara (TTU) merupakan salah satu daerah dimana perkembangan ternak Babi Landrace masih sangat minim dan belum banyak dipelihara oleh masyarakat TTU, oleh karena itu perlu dikembangkan selain untuk mengubah mutu genetik ternak babi lokal, melalui ternak Babi Landrace yang karena memiliki kemampuan beranak yang baik diharapkan dapat membuka suatu usaha baru, yang pada gilirannya dapat meningkatkan pendapatan petani.

Kemampuan kinerja reproduksi ternak babi dipengaruhi oleh beberapa faktor yang antara lain: kualitas spermatozoa dari ternak pejantan, daya tahan spermatozoa hidup dalam mempertahankan kualitas spermatozoa dan ketrampilan inseminator dalam melakukan inseminasi pada ternak babi tersebut. Salah satu cara yang digunakan dalam mempertahankan kualitas spermatozoa dan daya tahan spermatozoa hidup yaitu kejutan dingin (cold shock).

Kejutan dingin (cold shock) digunakan untuk mengetahui kualitas spermatozoa dan kerusakan spermatozoa akibat penyimpanan dalam suhu yang rendah. Berdasarkan latar belakang tersebut maka dilakukan penelitian yang berjudul "Uji Cold Shock Spermatozoa Babi Landrace Terhadap Viabilitas dan pH Semen Dengan Lama Waktu Berbeda". Tujuan dari penelitian ini untuk mengetahui pengaruh kejutan dingin (cold shock) spermatozoa Babi Landrace terhadap viabilitas dan pH semen dengan lama waktu yang berbeda. Kegunaan dari penelitian ini sebagai sumber informasi ilmiah dalam pengembangan ilmu pengetahuan khususnya dibidang peternakan dan sebagai sumber informasi bagi masyarakat tentang pengaruh kejutan dingin (cold shock) terhadap viabilitas dan $\mathrm{pH}$ semen dengan menggunakan semen pejantan unggul Babi Landrace.

\section{Metode}

Penelitian ini dilaksanakan di Tunbakun, Kelurahan Kefamenanu Tengah (penampungan semen di kandang peternak), dan perlakuan cold shock di Laboratorium Fakultas Pertanian Universitas Timor. Penelitian dilaksanakan selama 2 bulan, dimulai dari bulan Februari sampai dengan bulan Maret 2016.

Ternak yang digunakan dalam penelitian ini adalah satu ekor ternak pejantan Babi Landrace dengan umur \pm 1 tahun 8 bulan. Alat yang digunakan dalam penelitian ini adalah: Pipet tetes, Tabung penampung semen berskala, Kertas tissue, Hand Counter, Mikroskop, Haemocytometer, Gelas objek, Gelas penutup, Kertas indicator, Vagina buatan dan kertas lakmus. Bahan yang digunakan dalam penelitian ini adalah: Semen cair Babi Landrace, Es batu, Larutan eosin, Alkohol.

Penelitian ini menggunakan metode experiment laboratorium menggunakan Rancangan Acak Lengkap ( RAL) terdiri dari 4 perlakuan dan 4 ulangan sehingga terdapat 16 unit percobaan. Perlakuan yang akan dilakukan adalah :

R0 : pengamatan spermatozoa yang disimpan selama 0 menit (kontrol)

$\mathrm{R} 1$ : pengamatan spermatozoa yang disimpan selama 30 menit

R2 : pengamatan spermatozoa yang disimpan selama 60 menit

R3 : pengamatan spermatozoa yang disimpan selama 90 menit
Variabel yang diteliti dalam penelitian ini adalah Viabilitas spermatozoa yakn daya tahan hidup spermatozoa (\%) dan $\mathrm{pH}$ semen atau derajat keasaman pada semen.

Data yang diperoleh dalam penelitian ini akan dianalisis dengan menggunakan alat analisis sidik ragam atau analisis of variance (ANOVA) Apabila terdapat perbedaan antara perlakuan akan dilanjutkan dengan uji jarak berganda Duncan (Steel and Torrie, 1993)

\section{Hasil dan Pembahasan}

Data awal evaluasi semen secara makroskopis dan mikroskopis pada penampungan menunjukan bahwa semen segar Babi Landrace memenuhi syarat dan layak untuk digunakan sebagai bahan penelitian. Data dari hasil penelitian dapat dilihat pada Tabel 1 .

\begin{tabular}{|c|c|c|}
\hline No & Uraian & Hasil Evaluasi \\
\hline 1 & Volume & $200 \mathrm{ml}$ \\
\hline 2 & $\mathrm{Bau}$ & Bau Khas Semen Babi \\
\hline 3 & Konsistensi & Encer \\
\hline 4 & Warna semen & Putih Susu \\
\hline 5 & Gerakan Massa & +++ \\
\hline 6 & Gerakan Individu & 89.00 \\
\hline 7 & $\mathrm{pH}$ & 9 \\
\hline
\end{tabular}
Keterangan: Data diolah 2016.

\subsection{Pengaruh Perlakuan Cold Shock Terhadap Viabilitas Semen Babi} Landrace

Pengamatan terhadap viabilitas semen dilakukan menggunakan pewarnaan eosin. Spermatozoa yang hidup kepala tidak menyerap zat warna eosin sedangkan yang mati menyerap zat warna yaitu kepala merah atau merah muda. Pengruh perlakuan terhadap viabilitas setelah dikenakan perlakuan kejutan dingin (cold shock) dengan waktu yang berbeda dapat dilihat pada Tabel 2 .

Hasil analisis Uji t (t-test) menunjukan bahwa perbedaan pertambahan bobot badan antara kedua perlakuan tidak berbeda nyata $(P>0,05)$. Hal in menunjukkan bahwa ransum buatan mampu mengimbangi kemampuan ransum komersial dalam menghasilkan berat badan ternak. Hal ini karena semua bahan yang berasal dari bahan baku lokal seperti tepung gaplek, jagung giling, tepung daun turi, tepung ikan, kunyit, minyak kelapa serta molases memiliki nila nutrisi yang lengkap sehingga mampu memberikan nilai pertambahan bobot badan yang baik. Hal ini sesuai dengan pendapat (Ardana dan Harya Putra, 2008) yang menyatakan bahan pakan yang diberikan pada ternak yang memilik nilai kandungan nutrisi yang lengkap seperti karbohidrat, lemak, protein, asam amino, vitamin, serta air seimbang dan tepat sesuai kebutuhan ternak babi maka akan memberikan nilai pertambahan bobot badan yang memuaskan Lebih lanjut dijelaskan bahwa nilai energi metabolisme, protein, mineral, air, lemak yang tersedia dalam pakan mempunyai tujuan yaitu untuk kebutuhan pokok, pertumbuhan dan penggemukan.

Hasil analisis statistik menunjukkan bahwa rataan presentase viabilitas spermatozoa hidup setelah perlakuan kejut dingin (cold shock) dengan waktu yang berbeda menunjukan bahwa pengaruh perlakuan berbeda sangat nyata $(\mathrm{P}<0.01)$ dimana pada perlakuan (R1) 30 menit mempunyai rataan $55.38 \%$, (R2) 60 menit mempunyai rataan $33.63 \%$ dan yang terendah pada perlakuan (R3) waktu 90 menit mempunyai rataan $26.75 \%$.

Hasil penelitian ini menunjukan bahwa semakin lama waktu semen berada didalam cool box yakni 90 menit (R3) telah terjadi penurunan jumlah spermatozoa hidup sebesar $58.25 \%$ yakni selisih nilai rataan perlakuan (R0) $85.00 \%$ dikurangi nilai rataan (R3) $26.75 \%$. Perbedaan nilai rataan yang besar ini menunjukan bahwa spermatozoa tidak sanggup bertahan hidup jika terlalu 
lama dalam cool box yang diberi es batu. Hal ini kemungkinan karena spermatozoa mengalami cold shock sehingga menyebabkan pecahnya permeabilitas kepala spermatozoa sehingga menyebabkan spermatozoa mati. Namun hanya sekitar 20\% sampai $30 \%$ spermatozoa yang tidak mengalami kerusakan, lebih lanjut spermatozoa yang mengalami kerusakan kemungkinan masih motil, namun kemampuanya untuk membuahi masih diragukan (Ismaya, 2009)

Tabel 2. Pengaruh Perlakuan Cold Shock Terhadap Viabilitas Semen Babi Landrace

\begin{tabular}{|c|c|c|c|c|c|c|}
\hline \multirow{2}{*}{ Perlakuan } & \multicolumn{4}{|c|}{ Ulangan } & \multirow{2}{*}{ Jumlah } & \multirow{2}{*}{ Rataan } \\
\hline & 1 & 2 & 3 & 4 & & \\
\hline R0 & 89 & 80.5 & 86 & 84.5 & 340 & $85.00 \mathrm{~d}$ \\
\hline $\mathrm{R} 1$ & 52 & 56.5 & 54.5 & 58.5 & 221.5 & $55.38 \mathrm{c}$ \\
\hline $\mathrm{R} 2$ & 31.5 & 36.5 & 36 & 30.5 & 134.5 & $33.63 b$ \\
\hline R3 & 21.5 & 29.5 & 27 & 29 & 107 & $26.75 \mathrm{a}$ \\
\hline Total & & & & & 803 & 58.00 \\
\hline
\end{tabular}

Keteangan : Nilai rataan pada kolom dengan supercrip berbeda menunjukan perbedaan yang sangat nyata. $* *(\mathrm{p}<0.05)$

Hasil penelitian ini menunjukkan bahwa semakin lama semen disimpan dalam cold box semakin rendah persentase spermatozoa yang hidup. Hal ini sebagai akibat dari terjadinya cold shock yang di alami oleh spermatozoa dan kemungkinan lain disebabkan oleh penurunan suhu yang mendadak dalam cold box sehingga spermatozoa tidak sanggup berdaptasi dengan lingkungan yang sangat dingin dan kemudian mati. Selain itu karena terjadinya peningkatan $\mathrm{pH}$ semen dari 8 hingga 7 sehingga ada korelasi antara motilitas dan $\mathrm{pH}$ yakni jika terjadi peningkatan $\mathrm{pH}$ semen maka akan terjadi penurunan motilitas karena adanya peningkatan asam laktat (Toilehere, 1993).

Hasil analisis uji Duncan menunjukan bahwa pengaruh perlakuan diantara 4 perlakuan R0,s R1, R2 dan R3 berbeda sangat nyata ** $(\mathrm{P}<0.01)$, dimana terjadi penurunan presentase motilitas spermatozoa yang paling rendah pada lama penyimpanan 30 menit (R1) $55.38 \%$; kemudian diikuti pada penyimpanan 60 menit (R2) $33.63 \%$ dan yang paling tertinggi pada penyimpanan 90 menit (R3) $26.75 \%$.

\subsection{Pengaruh Perlakuan Cold Shock Terhadap pH Semen Babi Landrace}

Derajat keasaman pada saat penelitian adalah dominan 8. Semakin tinggi konsentrasi semakin rendah $\mathrm{pH}$ semen. Jika spermatozoa jumlahnya semakin banyak maka semakin banyak pula asam laktat yang dihasilkan sehingga semakin menurun pH semen. Hasil evaluasi awal semen menunjukan bahwa 89 $\%$ spermatozoa motil hal ini menggambarkan konsentrasi spermatozoa tinggi yang juga akan berpengaruh pada kondisi asam atau basah pada semen. Rataan $\mathrm{pH}$ semen pada penelitian dapat dilihat pada Tabel 3 .

Tabel 3. Rataan pH Semen Babi Landrace Dari Perlakuan

\begin{tabular}{ccccccc}
\hline \multirow{2}{*}{ Perlakuan } & \multicolumn{7}{c}{ Ulangan } & \multirow{2}{*}{ Jumlah } & \multirow{2}{*}{ Rataan } \\
\cline { 2 - 5 } & 1 & 2 & 3 & 4 & & \\
\hline R0 & 8 & 8 & 8 & 8 & 33 & $8.00^{\text {tn }}$ \\
R1 & 8 & 8 & 8 & 8 & 33 & $800^{\text {th }}$ \\
R2 & 8 & 8 & 7 & 8 & 31 & $7.75^{\text {tn }}$ \\
R3 & 8 & 7 & 7 & 7 & 29 & $7.25^{\text {tn }}$ \\
\hline Total & & & & & 125 & 31.00 \\
\hline
\end{tabular}

Keterangan: Keterangan: nilai rataan pada kolom dengan supersrcip berbeda menunjukan perbedaan yang Tidak nyata $(\mathrm{p}>0.01)$

Derajat keasaman $(\mathrm{pH})$ semen perlu diukur untuk memastikan bahwa cairan semen hasil penampungan memiliki karakteristik yang normal atau tidak. Hasil analisis statistik menunjukan pengaruh perlakuan berbeda tidak nyata ( $p>0.01$ ) dengan rataan $\mathrm{pH}$ yang diperoleh prlakuan (R0) 0 menit 8.00 (R1) 30 menit dengan rataan 8.00 kemudian terjadi perubahan pada setiap perlakuan dengan rataan, (R2) 60 menit 7.75 dan (R3) 90 menit 7.25.

Hasil penelitian ini menunjukan sedikit perbedaan nilai $\mathrm{pH}$ dimana terjadi peningkatan dan penurunan $\mathrm{pH}$ pada setiap perlakuan (R0-R3) spermatozoa mengalami cold shock karena terjadi penurunan suhu yang mendadak terutama dalam waktu yang makin lama (90 menit) sehingga terjadi penimbunan asam laktat yang dihasilkan oleh spermatozoa itu sendiri dan peningkatan $\mathrm{pH}$ berpengaruh terhadap penurunan viabilitas spermatozoa. Hal ini sesuai pendapat (Toilehere, 1993) pengaruh kejutan dingin terhadap sel spermatozoa menyebabkan terjadi penurunan motilitas dan abnormalitas spermatozoa selama proses penyimpanan.

\section{Kesimpulan}

Berdasarkan hasil penelitian dapat disimpulkan bahwa : penyimpanan semen segar Babi Landrace dalam cold box yang berisi es batu dengan lama waktu yang berbeda yaitu selama 0 menit, 30 menit, 60 menit, 90 menit mempunyai pengaruh yang sangat nyata $(\mathrm{P}<0.01)$ terhadap viabilitas spermatozoa hidup. Dimana R0 (0 menit) sebagai kontrol mempunyai presentase spermatozoa hidup rata-rata $85.00 \%, \mathrm{R} 1$ (30 menit) rata-rata $55.38 \%$, R2 (60 menit) rata-rata 33.63\%, dan R3 (90 menit) mempunyai ratarata $26.75 \%$. Sedangkan pengaruh kejutan dingin / cold shock terhadap derajat keasaman $(\mathrm{pH})$ berbeda tidak nyata $(\mathrm{p}>0.01)$ yakni nilai rataan adalah 31.00 namun telah terjadi peningkatan $\mathrm{pH}$ dari 8.00 menjadi 7.25 pada R3 (90 menit).

\section{Pustaka}

Ardana, I.B., Harya Putra, D.K., 2008. Ternak Babi. Manajemen Reproduksi, Produksi dan Penyakit. Udayana University Press, Denpasar.

Ismaya, 2009. Konservasi spermatozoa: perkembangan, hasil dan potensi di masa datang.

Steel, R.G.D., Torrie, J.H., 1993. Prinsip dan Prosedur statistika (diterjemahkan dari: Principles and Procedures of Statistic, penerjemah: B. Sumantri). PT. Gramedia, Jakarta.

Toilehere, M.R., 1993. Inseminasi Buatan Pada Ternak. Angkasa, Bandung. 